\title{
Structural-Semantic Patters with Suffixes Expressing Resemblance in Modern English and Modern Armenian.
}

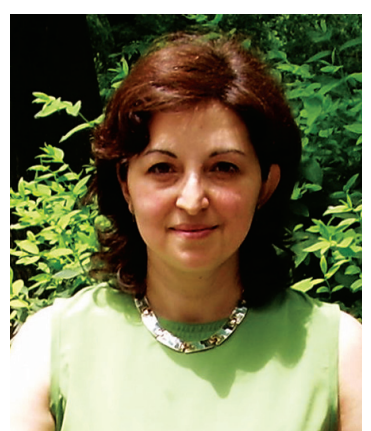

Lili Karapetyan

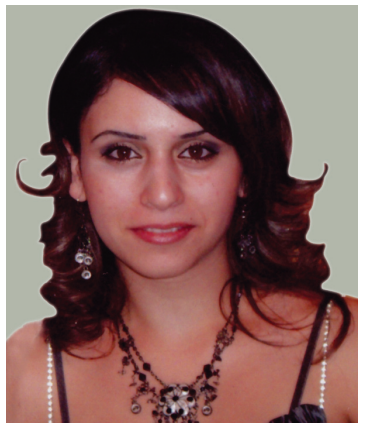

Armine Yakhnyan

There may be over a million words in the English

1 language. But most people do not know all of those words, and perhaps do not need to either. Knowledge of the most frequent words can help in general, as those words form a basic vocabulary. It has been estimated that about 100 words make up $50 \%$ of people's daily vocabulary. As we add to our knowledge of good English, we expand our mastery of the basic vocabulary. To promote this process it is of tremendous importance that linguists work out clearly defined rules and observations.

Since there are so many words, and since the long-term memory is rather slow in picking them up outside a natural English-speaking setting, a little semantics is of great help. Thus, common factors involved in many words help to comprehend words, which in its turn facilitates memorizing.

Some words consist of "building blocks" that are fit together. To find out how these building blocks are put together we shall have to turn to word-formation: the main basis for so many words existing in a language.

As P.Karashchuk puts on, word-formation must first of all deal with the investigation of the problem "how the words are built" which will help us to solve the problem "how to build a word" (Karashchuk 1997)

Our study focuses on the formation of derivative adjectives containing suffixes expressing resemblance in

Modern English and Armenian on the synchronic level.

The choice of derivative adjectives is accounted for by the fact that adjectives form a considerable part of the word-stock of the English and Armenian languages and that both languages are rich in affixes (especially in suffixes). As it is known the number of simple adjectives in all the languages is extremely limited. Most adjectives have been formed by means of affixation and compounding.

The problems connected with the English word-formation have been studied by $\mathrm{H}$. Marchand, H.Koziol, I.Arnold, V.Adams, Z.Kharitonchik, Y.Kubriakova, P.Karashtchuk and others. The contribution of Armenian linguists to this issue is of no less importance as evident in the works by M.Abeghian, E.Aghayan, A.Mourvalyan, H.Ohanyan and 
others. At present the comparative study of word-building systems of native and foreign languages (in the case discussed Armenian and English) is of great significance as it reveals similarities and differences of word-building systems of the languages concerned.

While comparing word-building systems of related languages, linguists very often proceed from genetically identical affixes. Such an approach is not applicable to the languages under study since here we can hardly speak of etymological identity of affixes. However, it must be mentioned that the Indo-European languages under investigation (English and Armenian) have some similarities in the means and ways of word-formation, morphemic composition of words, grouping words into parts of speech, word-building relations between parts of speech although they belong to different morphological types of languages: English is basically an analytical language, while Armenian is mainly an agglutinative one.

Word-building patterns help to better understand the peculiarities of word-building systems in both languages. As H.Marchand, Z.Kharitonchik, Y.Kubriakova, we also have tried to proceed from these patterns in our study.

To describe the system of suffixation of adjectives in Modern English and Armenian we have found the following productive word-building patterns:

$\begin{array}{ll}\text { English } & \text { Armenian } \\ \mathrm{N}+\mathrm{S}=\mathrm{A} & \mathrm{N}+\mathrm{S}=\mathrm{A} \\ \mathrm{V}+\mathrm{S}=\mathrm{A} & \mathrm{V}+\mathrm{S}=\mathrm{A} \\ \mathrm{Adj}+\mathrm{S}=\mathrm{A} & \mathrm{Adj}+\mathrm{S}=\mathrm{A} \\ \mathrm{Num}+\mathrm{S}=\mathrm{A} & \mathrm{Num}+\mathrm{S}=\mathrm{A} \\ \mathrm{Adv}+\mathrm{S}=\mathrm{A} & \end{array}$

In these patterns $\mathrm{N}$ stands for noun stems, $\mathrm{V}$ - for verb stems, Adj - for adjective stems, Num - for numeral stems, Adv - for adverb stems, S - for suffixes and A - for derived adjectives.

Proceeding from the assumption that each pattern possesses a structure and meaning, we have studied not only the structure of the patterns, but their meanings as well, both of the stems and affixes and dynamics of their interrelation, which is very important because in order to coin words it is necessary not only to know the morphemes of which they consist but also to reveal their recurrent regular combinations and the relationship existing between them. So, alongside lexical and grammatical meanings of a derived word we distinguish its word-building meaning, by which we understand the meaning of the derived word which is inferred from the meanings of the structural components of the pattern.

As within the limits of the present article it is impossible to give an exhaustive description of the stems and affixes functioning in the above mentioned word-building patterns, we shall confine ourselves to the study of suffixes expressing resemblance in Modern English and Modern Armenian.

Thus, on the structural level we single out the following structural patterns with 
suffixes expressing resemblance in Modern English and Armenian, which are listed according to the degree of productivity:

\begin{tabular}{|c|c|}
\hline English & Armenian \\
\hline $\mathrm{N}+$-like $=\mathrm{A}$ & $\mathrm{N}+-m \varphi \mathrm{uG}=\mathrm{A}$ \\
\hline $\mathrm{N}+-\mathrm{ish}=\mathrm{A}$ & $N+-m, \rho G=A$ \\
\hline$N+-y=A$ & $\mathrm{~N}+-\mathrm{t}=\mathrm{A}$ \\
\hline$N+-1 y=A$ & $\operatorname{Adj}+-m\lfloor n\llcorner G=A$ \\
\hline
\end{tabular}

Adjectives formed after these patterns have the following meanings:

$\mathrm{A}_{1}$ - resembling in appearance to the noun expressed by the derivational base

$\mathrm{A}_{2}$ - resembling in behavior to the noun expressed by the derivational base

$\mathrm{A}_{3}$ - resembling in qualities to the noun expressed by the derivational base

$\mathrm{A}_{4}$ - resembling in character to the noun expressed by the derivational base

$\mathrm{A}_{5}$ - resembling in a weak degree to the quality of the adjective expressed by the derivational base

A thorough examination of the above mentioned patterns reveals the following: like:

in the structural pattern $\mathrm{N}+$-like $=\mathrm{A}$ we differentiate three meanings of the suffix -

- like $_{1}$ - resemblance in appearance

- like $_{2}$ - resemblance in behaviour

-like $e_{3}$ - resemblance in quality

The suffix -like is used to convert nouns into adjectives expressing resemblance to the noun; as, manlike, like a man; childlike, like a child; godlike, like a god, etc. Such compounds are readily formed whenever convenient such as crescentlike, serpentlike, hairlike.

Thus, on the structural-semantic level we single out the following patterns with the suffix in question:

$\mathrm{N}_{1}+$-like $\mathrm{e}_{1}=\mathrm{A}_{1}$ (bridelike, groomlike, girllike, boylike, ladylike, babylike, childlike, workmanlike), where $\mathrm{N}_{1}$ stands for nouns denoting persons.

$\mathrm{N}_{1}+-$ like $_{2}=\mathrm{A}_{2}$ (childlike, babylike, ladylike, motherlike, fatherlike, brotherlike, sisterlike).

$\mathrm{N}_{3}+-$ like $\mathrm{e}_{1}=\mathrm{A}_{1}$ (batlike, wolflike, serpentlike, foxlike, piglike, ratlike, lionlike, mouselike, cocklike, sheeplike, birdlike, catlike, doglike), where $\mathrm{N}_{3}$ stands for animal names.

$\mathrm{N}_{8}+-$ like $_{1}=\mathrm{A}_{1}$ (Londonlike, Moscowlike, Parislike, Berlinlike, Senalike, Volgalike), where $\mathrm{N}_{8}$ stands for geographical names.

$\mathrm{N}_{6}+{ }_{-1 i k e_{3}}=\mathrm{A}_{3}$ (goldlike, pearllike, glasslike, silverlike), where $\mathrm{N}_{6}$ stands for nouns of material.

The Armenian equivalents of the suffix -like appear to be - шцшu and -»: 


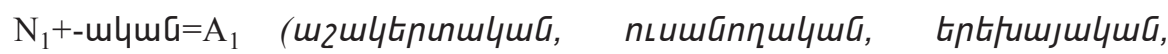
иппшлшцша, шпгцшцша)

(cp. pupillike, studentlike, childlike, boylike, girllike), where $\mathrm{N}_{1}$ stands for nouns denoting persons.

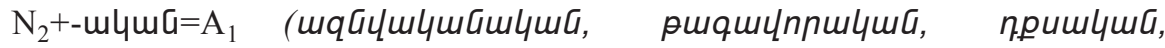
qhaцnnшцша, punnamluma)

(cp. noblelike, kinglike, dukelike, soldierlike, baronlike), where $\mathrm{N}_{2}$ stands for nouns

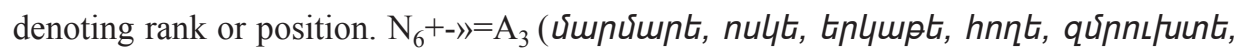

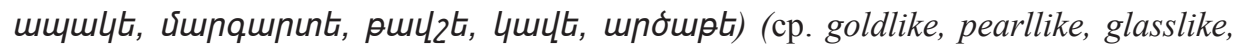
silverlike), where $\mathrm{N}_{6}$ stands for nouns of material.

Another suffix expressing resemblance is the suffix $-i s h$. The suffix -ish derives from the Old English suffix -isc. We distinguish the following types of -ish:

-ish ${ }_{1}$ - resemblance in appearance

$-i s h_{2}$ - resemblance in behaviour

$-i s h_{3}$ - resemblance in a weak degree of quality

-ish 4 - resemblance in character

So, the structural pattern $\mathrm{N}+$-ish $=$ A produces the following structural-semantic patterns:

$\mathrm{N}_{1}+-\mathrm{ish}_{1}=\mathrm{A}_{1}$ (babyish, girlish, boyish, childish), where $\mathrm{N}_{1}$ stands for nouns denoting persons.

$\mathrm{N}_{1}+-\mathrm{ish}_{2}=\mathrm{A}_{2}$ (babyish, girlish, boyish, childish).

$\mathrm{N}_{3}+-$ ish $_{3}=\mathrm{A}_{1}$ (wolfish, foxish, piggish, cattish, cockish, doggish, battish, rattish, bearish, goatish), where $\mathrm{N}_{3}$ stands for animal names.

$\mathrm{N}_{5}+$-ish ${ }_{1}=\mathrm{A}_{1}$ (Queen Annish, King Arthurish, Princess Dianish, Mark Twainish, Lawerencish, Freudish), where $\mathrm{N}_{5}$ stands for personal names.

$\mathrm{Adj}_{1}+-\mathrm{ish}_{3}=\mathrm{A}_{5}$ (brownish, reddish, bluish, blackish, greenish), where $\mathrm{Adj}_{1}$ stands for adjectives denoting colour.

$\mathrm{Adj}_{2}+\mathrm{ish}_{3}=\mathrm{A}_{5}$ (roundish ,longish, shortish), where $\mathrm{Adj}_{2}$ stands for adjectives denoting shape.

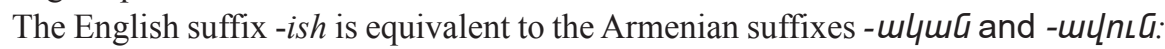

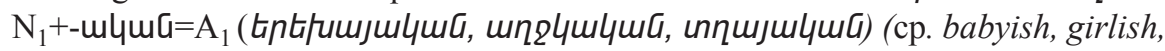
boyish, childish).

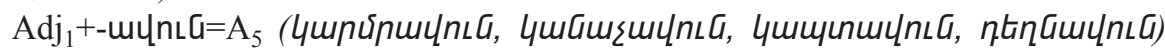
(cp. reddish, greenish, bluish, yellowish), where $\mathrm{Adj}_{1}$ stands for adjectives denoting colour.

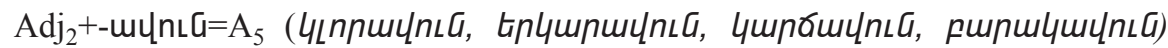
(cp. Roundish, longish, shortish), where $\mathrm{Adj}_{2}$ stands for adjectives denoting shape.

The next suffix to be analysed is $-y$, which descends from the Old English adjective suffix -ig.

The general sense of the suffix is 'having the qualities of' or 'similar to something' 
as in doggy, catty, piggy or 'full of' which is denoted by the stem to which it is added, as $i c y=(1)$ of the nature of or having the coldness, hardness of ice; (2) full of or covered with ice. Such adjectives were numerous in Old English, and large additions were made at particular periods, especially in the $14^{\text {th }}$ century as dirty, healthy, saucy. From the $13^{\text {th }}$ century the suffix $-y$ has been added to verb-stems to express the meaning 'inclined or apt to' or 'giving occasion to' a certain action as blowy, drowsy, sticky. Some monosyllabic adjectives were extended by means of this suffix as early as the $15^{\text {th }}$ century, as chilly, dusky, vasty. A sense 'addicted to' or 'similar to', as in doggy, horsy, is of modern growth. The suffix has frequently come to express the same notion as -ish, particularly with colour-epithets, and especially when these are used as quasi-adverbs, as greeny-blue. (Marchand 1960: 287)

Before passing to the study of word-building patterns containing the suffix $-y$ we shall consider the meanings of the suffix in question:

$-y_{1}$ - resemblance in appearance

$-y_{2}$ - resemblance in character

$-y_{3}-$ resemblance in a weak degree of quality

In the structural pattern $\mathrm{N}+\mathrm{y}=\mathrm{A}$ the following structural-semantic patterns are observed:

$\mathrm{N}_{3}+-\mathrm{y}_{1}=\mathrm{A}_{1}$ (batty, beary, foxy, doggy, dovy, spidery, mousy, wolfy, piggy, catty, horsy, liony), where $\mathrm{N}_{3}$ stands for names of animals.

$\mathrm{N}_{3}+-\mathrm{y}_{2}=\mathrm{A}_{4}$ (foxy, doggy, mousy, wolfy, piggy, catty, horsy, liony).

$\mathrm{N}_{9}+-y_{3}=\mathrm{A}_{3}$ (fishy, soucy, meaty, porky, beefy, minty, milky, peppery, winy, beery), where $\mathrm{N}_{9}$ stands for names of foods and drinks.

The Armenian equivalent of the English suffix $-y$ is $-m$ JhG, though not every structural pattern has its equivalent in Armenian:

$\mathrm{N}_{9}+-m j h G=\mathrm{A}_{3}$ ( LmpGimshG, ăLGushG) (cp. milky, fishy), where $\mathrm{N}_{9}$ stands for names of foods and drinks.

No equivalents have been found for meaty, porky, beefy, minty and etc.

The last suffix expressing resemblance is the derivational suffix $-l y$. The suffix $-l y$ basically adds to the notion of 'like' or 'in this way' to nouns. Its oldest spellings were variations of -like, such as -lic, -lich and

$-l i c h e$, eventually reduced to $-l i$ or $-l y$. Words such as goodly, stately, and kindly reflect a more purely grammatical use of $-l y$ to mean 'having to do with'. The origins of their meanings are often usages of the base word that are uncommon or obsolete now. (Marchand 1960: 267)

The suffix appears only in the $\mathrm{N}+-\mathrm{ly}=\mathrm{A}$ structural-semantic pattern and expresses the meaning 'similar to'. Words such as queenly, kingly and cowardly, fatherly mean 'like a queen, king / coward, father'; the former refers to appearance or behavior, while the latter is more particularly about behavior alone. So in the examples given below the suffix in question has the following two meanings:

$-l y_{1}-$ resemblance in appearance 
$-1 y_{2}-$ resemblance in behaviour

In the structural pattern $\mathrm{N}+-\mathrm{ly}=\mathrm{A}$ the following structural-semantic patterns are singled out:

$\mathrm{N}_{1}+-\mathrm{ly}_{2}=\mathrm{A}_{2}$ (bridely, groomly, burglarly, ghostly, manly, wifely, womanly, childly), where $\mathrm{N}_{1}$ stands for nouns

denoting persons.

$\mathrm{N}_{2}+-\mathrm{l}_{1}=\mathrm{A}_{2}$ (baronly, kingly, queenly, dukely, priestly, monkly, popely, princely, soldierly), where $\mathrm{N}_{2}$ stands for nouns denoting rank or position.

$\mathrm{N}_{16}+-\mathrm{ly}_{2}=\mathrm{A}_{2}$ (motherly, fatherly, daughterly, cousinly, sisterly, brotherly), where $\mathrm{N}_{16}$ stands for nouns denoting kinship relations.

The Armenian equivalent of the suffix -ly appears to be - $u$ uluG:

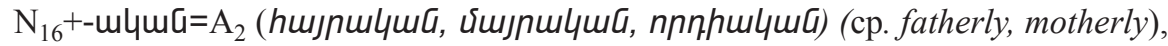
where $\mathrm{N}_{16}$ stands for nouns denoting kinship relations.

As it can be seen from the examples adduced in the article we see that suffixes expressing resemblance both in English and Armenian are chiefly added to N-stems. As a matter of fact only one suffix, the suffix -ish, can coin adjectives from Adj-stems. It has been noted that suffixes expressing resemblance deal mostly with concrete nouns, both common and proper. It is also noteworthy that in Modern English adjectives formed after these patterns are chiefly relative which is not characteristic of the Armenian language where derivative adjectives are mostly qualitative. This lies in the fact that in Modern Armenian suffixes forming relative adjectives are few in number $(9$ suffixes in total) while in English qualitative adjectives are chiefly simple by their morphological composition.

Thus, our study of adjectives expressing resemblance in Modern English and Armenian has revealed some similarities and differences of word-building systems of both languages, which will go a long way in working out the typology of patterns. And our next logical step will be to study these patterns further to make a complete list of structural-semantic patterns of adjectives in Modern English and Armenian.

\section{References:}

1. Akhmanova, O. (1979) Patterns and Productivity. Moscow: MGU

2. Ginzburg, R.S. (1979) A Course in Modern English Lexicology. Moscow: Vishaya Shkola.

3. Marchand, H. (1960) The Categories and Types of Present Day English WordFormation. Wiesbaden: Otto Harrassowitz.

4. Eloyan, M. (1962) Zhamanakakits hayereni atsantsnery. Yerevan: H.Kh.S.H. Git. Akademia.

5. Galstyan, M.A. (1975) Goyakan himqerits atsakan kazmogh verjatsantsnery zhamanakakits hayerenum. Yerevan: Yerevani hamals. hrat.

6. Karapetyan, L. ( 2007) The Role of Derivative Word-Building Patterns in Enriching 
Learners'Vocabulary // Armenian Folia Anglistika. / Yerevan, N1(3).

7. Karapetyan, L. (1998) Verjatsantsavor kaghaparneri karutsvatsqa-imastayin verlutsutian mi qani hartser zhamanakakits anglereni yev hayereni handipadrutyamb // Otar Lezunery Bardzraguyn Dprotsum. Yerevan: Yerevani hamals. hrat.

8. Karashchuk, P.M. (1997) Slovoobrazovaniye angliyskogo yazika. Moskva: Nauka.

9. Kharitonchik, Z.A. (1971) Semantika Proizvodnogo Slova. Avtoreferat Candidatskoy Dissertatsii. Moskva, M.G.P.I.

10. Kubriakova, Y.S. (1965) Chto takoye slovoobrazovaniye. Moskva: Nauka.

11. (1985) The Oxford Dictionary of English Etymology. Oxford: Oxford University Press.

12. Asmangulyan, H.A. (1984) Angleren-hayeren bararan. Yerevan: Hayastan hrat.

13. (1978) The Short Oxford English Dictionary on Historical Principles. Oxford: Clarendon Press. Vol. 2.

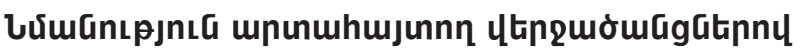

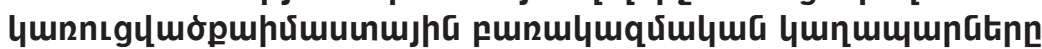

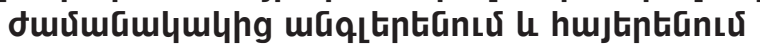

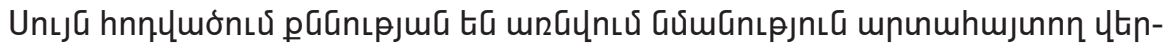

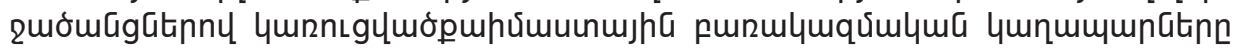

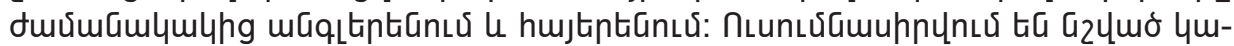

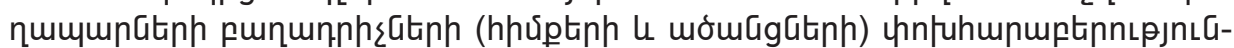

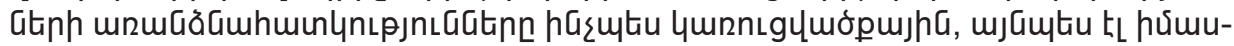

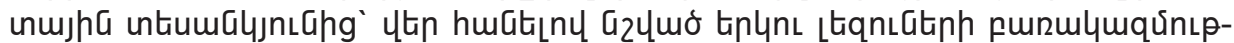

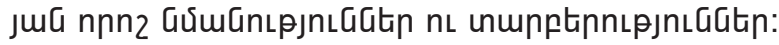

